\author{
Ш.М. Мухтарова ${ }^{1}$ А.С. Мусраунова ${ }^{2}$ \\ ${ }^{1,2}$ Карагандинский государственный университет им. академика Е.А. Букетова \\ г.Караганда, Казахстан

\section{НАЦИОНАЛЬНАЯ ШКОЛА И ПОДГОТОВКА ПЕДАГОГИЧЕСКИХ КАДРОВ В КАЗАХСТАНЕ ( 20-30-е гг. ХХ века)}

\begin{abstract}
Аннотация
На основе историко-педагогических и архивных источников в статье проведен анализ состояния национальных школ и проблемы подготовки педагогических кадров в Казахстане в 20-30 - е годы 20 века. Авторы раскрывают сложные и противоречивые условия становления и развития национальных школ в первые годы советской власти. Общими трудностями в организации и работе национальных школ было слабое учебно-методическое обеспечение образовательного процесса на родном для учащихся языке, скудная учебно-материальная база и острая нехватка национальных педагогических кадров. В статье прослеживается развитие этнического компонента в содержании образования национальных школ и в системе подготовки учителей, а также проблема их учебного обеспечения. Авторами статьи осуществлен анализ архивных источников, в которых содержится информация о содержании подготовки учителей для национальных школ в КазПИ им.Абая, первой кузницы педагогических кадров с высшим образованием, описана сеть подготовки национальных педагогических кадров в Казахстане и за ее пределами в 20-30-ые годы 20 века.

Ключевые слова: национальная школа, этнический компонент, содержание образования, высшее педагогическое образование, национальные педагогические кадры, многонациональное образование, стабильный учебник.
\end{abstract}

\author{
Ш.М. Мухтарова ${ }^{1}$, А.С. Мусраунова ${ }^{2}$ \\ 1,2 академик Е.А. Бөкетов атындавы Қараванды мемлекеттік университеті \\ Қараванды қ., Қазақстан

\section{ҚАЗАҚСТАНДАҒЫ ҰЛТТЫҚ МЕКТЕП ЖӘНЕ ПЕДАГОГИКАЛЫҚ КАДРЛАРДЫ ДАЯРЛАУ (ХХ ғасырдЫң 20-30 жж.)}

\begin{abstract}
Aнцдаmna
Мақаладағы тарихи-педагогикалық және мұрағат көздері Қазақстандағы 20-шы ғасырдың 20-30жылдарындағы педагогикалық кадрларды даярлау және ұлттық мектептердің проблемаларын талдау негізінде жсалған. Авторлар Кеңес өкіметінің алғашқы жылдарында ұлттық мектептердің қалыптасуы мен дамуының күрделі және қарама-қайшы жағдайларын ашып көрсетеді. Ұлттық мектептерді ұйымдастыруы мен жұмысындағы жалпы қиындықтар оқушыларға ана тілінде білім беру процесінің оқу-әдістемелік қамтамасыз етілуінің нашарлығы, оқу-материалдық базасының аздығы және ұлттық педагогикалық кадрлардың жетіспеушілігі болды.Мақалада ұлттық мектептердің білім беру мазмұнында және мұғалімдерді даярлау жүйесінде этникалық компоненттің дамуы, сондай-ақ оларды оқытуды қамтамасыз ету проблемасы байқалады. Мақала авторлары мұрағаттық дерек көздеріне талдау жасаған, онда Абай атындағы ҚазПИ ұлттық мектебі үшін мұғалімдер даярлығының мазмұны туралы ақпарат бар, жоғары білімді педагогикалық кадрлардың бірінші ұстасы, 20 ғасырдың 20-30 жылдары Қазақстанда және одан тыс жерлерде ұлттық педагогикалық кадрларды даярлау жүйесі сипатталған.

Түйін сөздер: ұлттық мектеп, этникалық компонент, білім беру мазмұны, жоғары педагогикалық білім, ұлттық педагогикалық кадрлар, көпұлтты білім беру, тұрақты оқулық.
\end{abstract}


Sh. M. Mukhtaroval A. S. Musraunova ${ }^{2}$

\author{
${ }^{1,2}$ Karaganda state University named after academician E.A. Buketov \\ Karaganda, Kazakhstan
}

\title{
NATIONAL SCHOOL AND TRAINING OF TEACHERS IN KAZAKHSTAN (20th-30th XX century)
}

\begin{abstract}
Based on historical, pedagogical and archival sources, the article analysed the state of national schools and the problem of training of pedagogical personnel in Kazakhstan in the 20-30 years of the 20 century. The authors reveal difficult and contradictory conditions for the formation and development of national schools in the early years of Soviet power. The general difficulties in the organization and operation of national schools were the weak educational and methodological provision of education in the native language for students, the scarce educational and material base and the acute shortage of national pedagogical personnel. The article highlights the development of the ethnic component in the content of the education of national schools and in the system of teacher training, as well as the problem of their educational provision. The authors of the article analyzed archival sources, which contain information on the content of teacher training for national schools KazPI named after Abai, the first forge of pedagogical personnel with higher education, described the network of training of national pedagogical personnel in Kazakhstan and beyond in the 20th30 th years of the 20 century.

Keywords: national school, ethnic component, content of education, higher pedagogical education, national pedagogical personnel, multinational education, stable textbook.

Введение. Сфера образования для любого этноса во все времена была и остается средством сохранения себя как этнического целого. Национальная школа всегда играла роль ведущего посредника в системе отношений «личность - этнос - государство».

Творческие поиски решения проблемы сохранения этнического компонента в содержании образования и национального своеобразия культур народа Казахстана, вызывают научный интерес к опыту национального образования в республике, сложившегося в 20-30-ых годах прошлого столетия.

Объективными предпосылками исследования проблем национальной школы и подготовки национальных педагогических кадров в 20-30-е годы 20 века в Казахстане в современных условиях выступает ряд сложившихся противоречий: между нарастающим процессом глобализации и необходимостью сохранения национально-культурного наследия прошлых поколений посредством системы образования как достижения определенной этнокультурной цивилизации и духовнонравственного ориентира современного общества; между потребностью науки и практики в обеспечении национально-культурной самобытности образования и недостаточной разработанностью теории формирования этнического компонента в содержании образования в отечественной педагогике.

Цель данного исследования - представить полученные в ходе исследования теоретические и практические результаты в виде научного анализа проблем в развитии национальной школы и подготовки национальных педагогических кадров в 20-30-е годы 20 века в Казахстане и их авторской интерпретации.
\end{abstract}

Объект исследования: история возникновения и развития многонациональных школ и подготовка национальных педагогических кадров в 20-30-е годы 20 века в Казахстане.

Теоретическая и практическая значимость настоящего исследования заключается в анализе и научной интерпретации неопубликованных в педагогических исследованиях фрагментов архивных документов, способствующих восстановлению более целостной историко-педагогической картины развития национальной школы и подготовки национальных педагогических кадров в Казахстане в 2030-е годы 20 века, которые могут быть использованы в научных историко-педагогических и другого рода исследованиях, а также - в лекционных и семинарских занятиях в подготовке будущих педагогов по курсу «История педагогики».

Научная новизна исследования заключается в выявлении исторических материалов об образовании в 20-30-е годы 20 века в Казахстане, их анализе, авторской интерпретации, что будет содействовать более углубленному и детальному восполнению отечественных историкопедагогических источников. 
Актуальность настоящей статьи заключается в том, что этнокультурное образование национальных школ и процесс подготовки национальных педагогических кадров в 20-30-е годы 20 века в Казахстане является бесценным духовным наследием прошлых поколений, частью истории педагогики Казахстана и подлежит дальнейшему исследованию для восстановления объективности и использования позитивного опыта развития этнического компонента в содержании образования в условиях нарастающей глобализации, вестернизации, размывания ценностных ориентаций молодежи, необходимости формирования национального самосознания подрастающих поколений.

Понятие «национальная школа» рассматривается нами как этносоциокультурный феномен, сформировавшийся в образовательном пространстве в условиях многоязычия и поликультурности. Современная интерпретация понятия «национальная школа» отличается не только обучением на родном языке, но, главным образом, наполнением учебно-воспитательного процесса этническим компонентом. Так, отмечено, что национальное образовательное учреждение отличается от других представленностью этнического компонента во всех звеньях учебно-воспитательного процесса.

Понятие «этнический компонент в содержании образования» понимается авторами как гуманитарный комплекс знаний, генетически обусловленный развитием самосознания этноса. Этнический компонент является ведущим принципом отбора и организации содержания образования, отражающегося в учебном плане, в программных документах, учебниках и учебных пособиях и т.д. Таким образом, особенностью национальной школы является реализация этнического компонента образования в содержании целостного педагогического процесса. Ее главным признаком выступает ориентация на формирование цельной личности с духовными устремлениями: становление интеллигентного представителя своего народа, носителя и созидателя национальной культуры, знающего и уважающего ценности других народов, способного на конструктивное межэтническое общение. В связи с этим этнический компонент в содержании образования должен быть фундаментом педагогического образования в целом, что объясняется важностью профессиональной подготовки будущих учителей в деле воспитания подрастающего поколения.

Методология исследования. Методологию настоящего исследования составили: философский принцип общего, единичного и особенного, принципы методологических подходов (системноструктурного, логико-исторического, аксиологического, этнокультурного, поликультурного); ведущие принципы историко-педагогического исследования: принцип объективности, принцип единства логического и исторического, принцип концептуального единства исследования; философские, этнокультурологические, исторические, историко-педагогические концепции, раскрывающие сущность понятия «национальная школа» и основные положения теории формирования этического компонента в содержании образования. Использование этнодидактического подхода в качестве методологического в контексте нашей проблемы становится возможным в рамках реализации принципа ориентации ценностей этнического компонента на духовно-нравственное развитие личности. Труды исследователей и архивные материалы явились источниковедческой базой исследования по данной теме.

Методы исследования: системно-структурный, феноменологический анализ понятий историкопедагогической, философской, культурологической, этнологической наук по проблеме исследования, методы аналогии и обобщения, классификации, анализ архивных документов, исторических источников и учебной документации вузов и др.

История национального образования в Казахстане была в центре научного внимания исследователей разных лет. Большой вклад в изучение истории национального образования в Казахстане внесли ученые Б.Альмухамбетов, А.Сембаев, И.Я.Гармс, А.П.Герасимова, Ш.Кокумбаев, К.Б.Бержанов, Т.Т.Тажибаев, С.Мусин, Р.Иржанова, И.Б.Мадин, А.Т.Колмаков, Г.М.Храпченков, К.Кунантаева, А.П.Сейтешев, К.Б.Жарикбаев, С.К.Калиев, К.Б.Сейталиев, А.Н.Ильясова и др. Проблемы истории становления и развития школ национальных меньшинств Казахстана в различных хронологических рамках рассматривались в работах Г.Смагуловой, Е.Тулемисова, А.С.Ким, Б.С.Азизовой, Б.И.Хан, Н.О.Жетпеисовой и др.

Результаты исследовании. Началу многонационального образования в Казахстане положило постановление Наркомпроса РСФСР от 31 октября 1918 года «О школах для национальных меньшинств». Всем национальностям предоставлялось право открывать школы и вузы на их родном языке.

О потребности национальных школ в Казахстане уже в первые годы Советской власти свидетельствует национальный состав населения Казахстана по данным переписи 1926 года. 
Согласно данной переписи в Казахстане проживали 3627612 - казахов, 1275055 - русских, 129399 узбеков, 860201 - украинцев, 79758 - татар, 51803 - таранчу, 51094 - немцев, 27327 представителей мордвы, 25584 - белорусов, 10200 - киргизов, 8455 - дунган и представители других национальностей. Всего в Казахстане в 1926 году проживало 6.198 .467 человек, среди них представители 85 национальностей. (Сведения взяты по переписи населения за 1926 год в старых границах Казахстана, без Каракалпакии) [1].

В соответствии с компактным проживанием этнических групп в Казахстане в 1924/25 учебном году функционировали 192 национальные школы, в том числе - казахские, русские, немецкие, татарские, узбекские, дунганские, уйгурские [2]. Наряду с этим существовало большое количество разных двуязычных школ: русско-татарские, русско-казахские, русско-узбекские, русско-немецкие, казахско-татарские, казахско-узбекские.

Развитие национальных школ сопровождалось политикой «коренизации» населения, которая проводилась повсеместно на территории СССР. Изучение языка казахского народа как коренной национальности представителями других этносов лежало в основе этой политики, которая предусматривала также и развитие родного языка. Помимо родного языка, этнический компонент в содержании образования национальных школ включал историю, географию, культуру и другие особенности изучаемого народа. В процессе изучения различных школьных предметов активно использовался краеведческий материал в процессе изучения различных школьных предметов. Элементы народной педагогики обогащали содержание образования, способствовали формированию этнической идентичности учащихся.

Динамичное становление и развитие национальных школ в Казахстане в 20-30 гг. прошлого века происходило в условиях сложной, порой противоречивой организации системы народного образования в республике [3, с. 71].

Общими трудностями в организации и работе национальных школ было слабое учебнометодическое обеспечение образовательного процесса на родном для учащихся языке, скудная учебно-материальная база и острая нехватка национальных педагогических кадров. Такая ситуация существовала не только в Казахстане, но и на всей территории СССР. В осуществлении ленинской национальной политики по строительству национальных школ основным принципом являлось неукоснительное выполнение директив и постановлений центра с учетом местных особенностей.

В постановлении от 11 декабря 1931 года Пленум Комитета национальностей (Комнац) Наркомпроса РСФСР отмечались успехи в развитии национальных школ: введение среди национальностей РСФСР всеобщего обязательного начального обучения, а в городах и промышленных центрах и семилетнего. Обучение велось в начальных школах на 70 - ти языках. Как указано в постановлении, начался этап «завершения введения всеобуча на территориях всех АССР, $\mathrm{AO}$, нацрайонов, кроме распыленных народов Крайнего Севера». При всех достижениях национальных школ в деле ликвидации безграмотности и обучения на родном языке на Пленуме были указаны и серьезные недостатки в их работе: «Обучение в нацшколе не дает достаточного объема общеобразовательных знаний и неудовлетворительно разрешает задачу подготовки для техникумов и для высшей школы вполне грамотных людей, хорошо владеющих основами наук (физика, химия, математика, родной язык, география и др.)». В качестве важнейших причин «коренного недостатка» в деятельности национальных школ назывались следующие: «недостаточная их «коренизация»; слабая педагогическая квалификация значительного количества национальных педагогов; недостаточное обеспечение национальной школы коммунистически выдержанными учебниками, учебными пособиями и программно-методической литературой на родных языках учащихся; отсутствие конкретного дифференцированного руководства со стороны органов народного образования по отношению к отдельным национальностям» [4]. Таким образом, наряду с борьбой за устранение недостатков в работе национальных школ, им предъявлялись жесткие требования, особенно в том, что касалось коммунистической идеологизации и политехнизации содержания обучения.

В этих условиях становление и развитие этнического компонента в содержании высшего педагогического образования неразрывно связано с проблемой подготовки национальных педагогических кадров.

Сеть национальных педагогических училищ в Казахстане насчитывала семь учебных заведений для уйгурской, корейской, украинской, немецкой, узбекской национальностей. В «Резолюции по докладу Комнаца Казахского Наркомпроса» от 15-19 августа 1931 года констатировалось заметное 
улучшение работы по обслуживанию национальностей Каз АССР. Отмечались заметные достижения в подготовке национальных кадров для школ. Был открыт Украинский педагогический техникум, налажены связи с педфаком Украины, организованы специальные восточные национальные техникумы в Джаркенте, узбекские отделения при Алма-Атинском и Кара-Калпакском педтехникумах, немецкое и татарское отделения при Петропавловском русском и казахском педтехникумах и дунганская школа - семилетка, разработан новый латинизированный алфавит для восточных национальностей КазАССР [5].

В подготовке национальных педагогических кадров Казахстана в 20-30 гг. XX века огромное содействие было оказано вузами РСФСР. В ряде источников по народному образованию в Казахстане, со ссылкой на архивные документы, приводятся статистические данные о командировании групп молодежи Казахстана на учебу в Москву, Ленинград, Саратов, Казань, Ташкент.

Специальная бронь для националов при приеме в учебные заведения, сыгравшая большую роль в деле подготовки национальных кадров союзных и автономных республик, автономных областей существовала до 1934 года. Далее бронь была заменена районированием педвузов по обслуживанию ими коренных национальностей автономных республик областей, а также территориальнонеобъединенных нацменьшинств в краях и областях. В списке пединститутов РСФСР, закрепленных за Казахстаном в то время входили: Астраханский, Саратовский, Куйбышевский, Свердловский, Омский, Томский [6].

Потребность в «националах» решалась не только посредством создания учительских курсов, техникумов, но и организацией высших учебных заведений в автономиях.

В октябре 1928 года в Казахстане был открыт первый педагогический институт, которому в 1935 году было присвоено имя выдающегося казахского просветителя Абая Кунанбаева. Существовавшие до него институты народного образования в Урде (Букеевский), Ташкенте, Оренбурге (затем, переведенный в Кзыл-Орду), Казахский институт просвещения в г. Верном были лишь отчасти востребованы как вузы из-за плохих организационных условий, малочисленности обучающихся, неукомплектованностью педагогическими кадрами и других трудностей и сыграли подготовительную роль в организации первого вуза Казахстана.

КазПИ им. Абая (ныне КазНПУ им. Абая) имеет огромные заслуги в деле подготовки педагогических кадров и развитии национальной культуры в республике. В стенах этого вуза работали видные деятели просвещения - М.Ауэзов, С.Сейфуллин, А.Байтурсынов, С.Муканов, Х.Досмухамедов, С.Асфендияров, Ш.Альжанов, М.Каратаев. За пять лет работы Казахским педагогическим институтом было выпущено 285 педагогов. С 1932 года были организованы специальные педагогические отделения с группами: школьно-педагогической, дошкольной и педологической. Первый выпуск КазПИ (1931г.) насчитывал 150 учителей с высшим образованием.

При быстро растущей потребности в национальных педагогических кадрах КазПИ уже не мог обеспечить запросы школ, техникумов. В связи с этим в марте 1932 года был открыт Уральский педагогический институт, в 1935-36 годах организованы учительские институты в Актюбинске, Алма-Ате, Кустанае, Караганде, Петропавловске. В начале 1934 года произошло знаменательное событие в культурной жизни Казахстана - открытие Казахского государственного университета им. С.М.Кирова, где были организованы физико-математический, биологический, химический и позднее - филологический факультеты. В подготовке учителей по заочному отделению в рассматриваемый нами период большую роль сыграл Казахский республиканский институт повышения квалификации кадров народного образования (ИПККНО)[3, с.73].

Результаты исследования. Анализ учебных планов КазПИ 30-х годов позволяет констатировать о наличии этнического компонента в содержании обучения в данном вузе.

В отчете КазПИ за 1930/31 учебный год сказано: «В учебные планы, полученные из Наркомпроса РСФСР, КазПИ внесены коррективы по линии включения в учебные планы дисциплин казахстанского назначения: 1) Казахский язык и методика казахского языка, 2) История казахского народа, 3) Экономика Казахстана, 4) Казахская литература, 5) Восточная литература, 6) Тюркская литература. Коррективы, внесенные в учебные планы, утверждены Наркомпросом Федерации» [7].

В учебных планах КазПИ в 1933-34 учебном году использовалось понятие «родной язык», изучалась история казахов, казахский язык на всех факультетах, независимо от основного языка обучения. Изучение национального языка в русских группах на факультете языка и литературы имело двойственное значение: использование знаний в области общего языкознания для 
сравнительно-сопоставительной характеристики разных языковых систем и общения. В объяснительной записке к «Учебному плану отделения русского языка и литературы» сказано: «Изучение национального языка имеет целью познакомить студента с языком другой системы. ...Изучение национального языка даст более прочную базу для методических обобщений, а также окажет помощь будущему преподавателю в том случае, если ему придется вести занятия с инонациональным населением» В числе специальных предметов для казахской секции отделения языка и литературы в учебный план КазПИ в эти годы включены турецкий язык, литература тюркских народов СССР, литература зарубежного Востока[8].

Проблемы подготовки национальных педагогических кадров решались и за пределами автономных республик, в так называемом «центре». Так, на историческом отделении Ленинградского историко (философско) лингвистического института в 1932/33 учебном году в цикле языков и литератур советского Востока (таджикский, узбекский, курдский, киргизский, туркменский) по специальности «История народов СССР» изучались дисциплины: «Национальные языки народов СССР», «История народов Запада и Востока», «История народов СССР». Таджикский цикл были включены: таджикский, персидский, арабский, узбекский языки, «Введение в таджикское языкознание», «История Средней Азии», «История таджикского языка», «История таджикской литературы»[9].

Многие проблемы в деле дифференциации подготовки педагогических кадров из лиц нерусской национальности решались Центральным научно-исследовательским педагогическим институтом национальностей, который был организован в 1931 году по постановлению Президиума ВЦИК. При нем была создана аспирантура с обучением на разных языках народов РСФСР и автономий.

Постановление ЦК ВКП (б) от 25 августа 1932 года «Об учебных программах и режиме начальной средней школы» способствовало дальнейшему развитию этнического компонента в содержании обучения национальных школ.

Важную роль в разработке содержания образования в казахской национальной школе сыграла плодотворная деятельность казахской интеллигенции в лице А.Байтурсынова, М.Дулатова, Ж.Аймаутова, М.Жумабаева, Х.Досмухамедова, С.Сейфуллина, М.Ауэзова, Ш.Альжанова, У.Джандосова, Т.Рыскулова, С.Мендешева и др. Несмотря на их разногласия в политических убеждениях в вопросах наполнения этническим компонентом содержания школьного образования они были едины. В разработанных ими учебниках для казахских школ этнический компонент был фундаментом содержания обучения. Они считали необходимым изучение учащимися истории, географии и культуры родного народа, знание фольклора, национальных традиций и обычаев, народных песен, игр, музыки, искусства и ремесел [3, с.75]. Интеллигенция того времени была убеждена в том, что национальная школа будет способствовать сохранению национальной самобытности казахского народа.

Издание «рабочих книг» и «рассыпных учебников» в первые годы советского просвещения, многократное проектирование учебников не давало систематических, прочных знаний учащимся национальных школ. Решением ЦК ВКП (б) от 12 февраля 1933 года «Об учебниках для начальной и средней школы» было дано указание о разработке «стабильных» учебников.

В условиях многонациональной среды перед Наркомпросами автономных республик, органами народного образования была поставлена чрезвычайно сложная задача по созданию стабильных учебников для национальной начальной и средней школы. Она порождала массу противоречий. Требования «стабильных» учебников для национальных школ приводило к идентичности их содержания и вытесняло национальное своеобразие. К марту 1933 года постановлением «О порядке издания национальных учебников в АССР и областях РСФСР» был определен перечень учебников, которые должны быть составлены для каждой отдельной национальности: буквари, грамматики, книги для чтения, хрестоматии по литературе для начальной школы, учебник русского языка, как для отдельной национальности, так и для групп национальностей. Специальные стабильные учебники предполагалось составлять на местах. Часть учебников для начальной и средней школы, не вошедших в данный перечень, должны были представлять собой перевод с единых стабильных учебников для обычной школы. Требовалась точность перевода, не допускающая смысловых искажений. К единым стабильным учебникам по истории предполагалось издавать дополнения, содержащие основные сведения по истории данной АССР, автономной области и национальных меньшинств. Было введено понятие «краевая учебная книга для начальной школы», представляющая собой учебное пособие, в котором содержатся знания о местном крае. Использование краевой книги 
при преподавании предметов должно дополнять и конкретизировать материал стабильного учебника. Например, краевая книга по естествознанию должна содержать материал о местном климате, местных растениях, насекомых, животных края и т.д.

Авторами и переводчиками стабильных учебников для казахской школы являлись в основной массе научные работники и студенты КазПИ, КазГУ. В 1930 году С.Муканов совместно с Б. Майлиным разработал пособие «Книгу для чтения по родной речи» и выпустил в соавторстве с К. Бекхожиным «Хрестоматию по казахской литературе» для школьников. С.Сейфуллин в 1932 году выпустил первый учебник по казахской литературе. В этом же году группа авторов, в составе которой были И.Джансугуров, С.Сейфуллин, Б. Майлин и др. разработали первую хрестоматию по казахской литературе. В последующие годы С.Сейфуллиным и У.Турманжановым была издана «Художественная литература» для V класса, М.Ауэзовым - хрестоматия по литературе для VII класса. Работа над выпуском хрестоматий и учебников по казахской литературе была продолжена М.Каратаевым, Г.Мусреповым, Е.Исмаиловым, Ж. Саиным и др. С.Бокаев принимал участие в составлении и переводе стабильных учебников по математике.

При разработке содержания учебников авторы, безусловно, придерживались принципа партийности, а также систематичности, доступности, учета национальных особенностей. Иллюстрированные учебники содержали сведения о национальных обычаях и традициях. Таким образом, проблема «стабильного учебника» в 1920-30-ых гг. стояла по значимости в одном ряду с подготовкой национальных кадров. Помимо учебников представителями казахской интеллигенции переводилась русская классическая и зарубежная литература.

Особые трудности в развитии письменного казахского языка и переводческого дела вызвал переход в 1929 году на латинскую графику. Об этих трудностях предупреждал ученый филолог А.Байтурсынов. Сравнивая недостатки и преимущества латинского и арабского языков, он выступал против перевода казахской письменности на латинский алфавит, что также послужило доводом противников для обвинения его в национализме и вследствие этого - подвержения репрессиям и навешивания ярлыка - «враг народа»[3, с.76].

Следует также отметить активность издательского дела в рассматриваемый период. О том, что издание книжной продукции на казахском языке в 30-ые гг. приобрело широкие масштабы. Увеличилось издание книг на языках народов, населяющих Казахстан.

Однако национально-культурный ренессанс в просвещении этносов Казахстана в советский период длился недолго. Переломным моментом в организации школ в Казахстане послужило постановление «О структуре начальной и средней школы», принятое в мае 1934 года. Данным постановлением по всему Советскому Союзу устанавливался единый тип школы, единые учебные планы, учебники, принципы обучения и воспитания молодого поколения.

Уже с 1937 года в Казахстане наблюдается резкий спад роста количества школ для национальных меньшинств на фоне разгула репрессий, доносов и постепенного свертывания сложившейся системы многонационального образования. Волна сталинских репрессий захватила национальную педагогическую интеллигенцию. Многим из них были предъявлены обвинения в национализме, в подрывной деятельности по изучению русского языка, в специальной организации национальных школ как «очагов буржуазно - националистического, антисоветского влияния на детей».

13 апреля 1938 года, руководствуясь постановлением ЦК ВКП (б) от 8 апреля 1938 года, Совнарком КазССР принял постановление «О реорганизации национальных школ», где был поставлен вопрос о ликвидации сети многонационального образования и реорганизации их в обычные образовательные учреждения советского типа, за исключением некоторых начальных уйгурских, узбекских, таджикских школ, расположенных в местах компактного проживания этих национальностей (Южно-Казахстанская область) [10]. Политика «изживания национального неравенства» в сфере образования для национальных меньшинств, провозглашенная «Решением декабрьского 1930г. Пленума ЦК и ЦКК ВКП (б) и национальной политики партии» резко пошла на убыль.

Дискуссия. Однако казахская национальная школа в 20-30-ые годы еще неуклонно шла по пути развития, сохраняя те этнокультурные традиции, которые были адаптированы к реалиям того времени. В условиях всеобего начального обучения быстрыми темпами развивалась сеть начальных, семилетних и средних казахских школ. С марта 1938 года в учебные планы национальных школ был введен русский язык. Повсеместно развернулась активная работа по изучению русского 
языка, который постепенно распространялся и на сферу социального общения, тем самым, вытесняя язык коренной национальности[3,с.77].

Критериями разработки содержания учебников к концу 30-ых стали возобладать, помимо классового подхода, их русификация.

Изменение национальной языковой политики сильно повлияло на содержание образования в вузах и национальных школах. Из школьного курса были изъяты предметы этнорегионального компонента: краеведение, родная история, география, сократилось количество часов на изучение родного языка. Аналогичная метаморфоза происходила и в педагогических учебных заведениях. Для сравнения приведем примеры из учебных планов КазПИ разных лет. Если в учебном плане факультета языка и литературы по специальности «Русский язык и литература», утвержденном 28 июня 1938 года, на изучение казахского языка было отведено 240 часов, казахской литературы - 120 часов, то в учебный план той же специальности от 16 июня 1941 года, эти дисциплины уже не входили.

Унификация и русификация содержания образования привела к потере исторической памяти, отторжению от исконных традиций народов Казахстана. Теория и практика интернационального воспитания в большей части советского периода страдала абстрактностью и односторонностью, т.к. не исходила из национальной самобытности культур народов Союза и находилась в зависимости от моноидеологического влияния партии.

Несмотря на противоречивый и чрезвычайно сложный путь истории многонационального просвещения в Казахстане в 20-30 годы XX века, это был период расцвета национальных культур и языков, творческого роста национальной интеллигенции, создавший благоприятные условия для развития этнического компонента в содержании образования. При всех недостатках системы многонационального образования в эти годы целесообразно исходить из позитивного историкопедагогического опыта в решении проблем образования в условиях поликультурной среды.

Заключение. Обращение к историческим источникам, свидетельствует о том, что становление системы национального образования проходило в сложных условиях лихолетья: последствия гражданской войны, национально-освободительное движение, политические разногласия, голод, острый недостаток в национальных кадрах, в учебниках и методической литературе. Но, несмотря на это национальная интеллигенция сумела донести до народных масс осознание роли социальных функций образования и культуры в деле построения нового, свободного от угнетения, общества.

Руководствуясь положениями социалистического строительства, национальная интеллигенция пыталась внести этническое своеобразие в становление национальной системы образования. Ярким примером этому является этнический компонент в содержании образования, присутствовавший в 2030-ых гг. XX века в школах и вузах. Казахский народ как этносоциальный организм был заинтересован в развитии этнического компонента, который, согласно теории Ю.В.Бромлея, является его непременным составляющим

Осмысление поставленных образовательной системой задач приводит к заключению, что этнический компонент в содержании образования, в целом, является одним из важных факторов, который отражается на формировании гражданской, этнической идентичности школьника, его ориентацией на поликультурность. При этом в современный период нами отмечается недостаточная трансляция идей этно и поликультурности и регионализации образования в педагогический процесс школы, особенно таких аспектов, как формирование национального самосознания подрастающего поколения, воспитание у них культуры межэтнического общения и толерантности.

Дальнейшее исследование настоящей проблемы видится в изучении преемственной связи национальных школ и подготовки профессиональных кадров на других исторических и современном этапах развития системы образования в Казахстане.

Список использованной литературы:

1. ЦГА РК. Ф. 81. ОП .3. Д. 106. Л. 16.

2. ЦГА РК. Ф. Р-81. On. 1. Д. 933. Л. 17.

3. Мухтарова Ш.М. Этнокультурный компонент в истории образования Казахстана (20-30-е г2. $Х Х$ века)//Педагогика.- 2006.- № 3.- с.70-77.

4. ЦГА РК. Ф. 81. Оп .3. Д. 106. Л.25.

5. ЦГА РК. Ф.81. On. 3. Д. 106. Л. 31.

6. ЦГА РК. Ф. 81. On. 3. Д. 842 . Л. 4 - 5. 
7. ЦГА РК. Ф.1142. Оп.1. Д.4. Л.20.

8. ЦГА РК. Ф. 1142. On. 1. Д. 7. Л. 55.

9. ЦГА. РК. Ф.1142.On.1. Д.10.Л.4.

10. ЦГА РК. Ф. 1692. On. 1. Д. 137. Л. 36

МРНТИ 14.01.11

https://doi.org/10.51889/2020-2.1728-5496.12

М.Е. Жангужинова ${ }^{1}$, К.К. Абилкаламова ${ }^{2}$, А.М. Сабитова ${ }^{3}$

${ }^{1}$ Казахская Национальная Академия Искусств им.Т. Жургенова, Алматы, Казахстан

2,3 Алматинский Технологический Университет, Алматы, Казахстан

\section{АНАЛИЗ МОДУЛЬНО-КОМПЕТЕНТНОСТНОГО ПОДХОДА В ПРОЕКТИРОВАНИИ ОБРАЗОВАТЕЛЬНОГО ПРОЦЕССА ВУЗОВ КАЗАХСТАНА И ЛАТВИИ}

Аннотация
В статье представлен теоретико-методологический сравнительный анализ модульнокомпетентностного подхода в проектировании образовательного процесса в вузах Латвии и Казахстана. Статья предназначена для обзорно-аналитического исследования диверсификации методик, технологий в двух постсоветских странахс различными траекториями образования. Исследование содержитанализ Законодательно-нормативных документов для специальностей «Профессиональное обучение», «Дизайн», «Сценография», а также сравнительный анализ организации педагогического процесса Формирования профессиональной компетентности Казахстана и Латвии. Целью исследования является проведение анализа двух видовобразовательного процесса в вузах, осуществляющих деятельность в рамках Болонской системы. Задачей исследования состоит ввыявленииразницы и схожести организации педагогического процесса в обоих странах, определение ихсистем,структурыи форм. Результатами исследования проявлены вразработкевыводов для образовательного процесса в вузах Казахстана.

Ключевые слова: Модульные Образовательные Программы (МОП), образовательный процесс в вузах, профессиональная компетентность.

$$
\begin{aligned}
& \text { М.Е. Жангужсинова }{ }^{1} \text {, К.К. Абилкаламова }{ }^{2} \text {, А.М. Сабитова } \\
& { }^{1} \text { T.Қ. Жүргенов атындавы Қазақ Ұлттық Өнер академиясы, } \\
& \text { Алматы, Қазақстан } \\
& \text { 2.3 Алматы технологиялық университеті, } \\
& \text { Алматы, Қазақстан }
\end{aligned}
$$

\section{ҚАЗАҚСТАН МЕН ЛАТВИЯДАҒЫ ЖОҒАРЫ ОҚУ ОРЫНДАРЫНДА БІЛІМ БЕРУ ПРОЦЕСІН ЖОБАЛАУДА МОДУЛЬДІК-ҚҰЗЫРЕТТІЛІК ТӘСІЛДІ ТАЛДАУ}

\section{Аңңдатпа}

Мақалада Латвия мен Қазақстанның жоғары оқу орындарында білім беру үдерісін жобалауда модульдік-құзыреттілік тәсілдің теориялық-әдіснамалық салыстырмалы талдауы берілген. Мақала әр түрлі білім траекториялары бар екі посткеңестік елдердегі әдістемелердің, технологиялардың диверсификациясын шолу-аналитикалық зерттеуге арналған. Зерттеу "Кәсіптік Оқыту", "Дизайн", "Сценография" мамандықтары үшін заңнамалық-нормативтік құжаттардың талдауын, сондай-ақ Қазақстан мен Латвияның кәсіби құзыреттілігін қалыптастырудың педагогикалық үдерісін ұйымдастырудың салыстырмалы талдауын қамтиды. Зерттеудің мақсаты Болон жүйесі шеңберінде қызметін жүзеге асыратын жоғары оқу орындарында білім беру процесінің екі түріне талдау жүргізу болып табылады. Зерттеу міндеті екі елде де Педагогикалық үдерісті ұйымдастырудың айырмашылығын және ұқсастығын анықтау, олардың системасын, құрылымы мен формаларын 